\title{
生分解性プラスチックス
}

\section{Biodegradable Plastics}

滝山栄一郎

Eiichiro Takiyama
最近, 実用化の動きが加速されつつあるかのように 見える生分解ポリマーは，いくつかの種類に分けられ るが，当社のビオノーレは，世界で最初の化学合成に よる脂肪族ポリエステルをベースとする生分解性ポリ マーである。

カローザス博士以来, 脂肪族ポリエステルでは有用 なポリマーは得られない, とのいわば常識が通用して いた感があるが，それも理由のないことではない.

第一にプラスチックとして利用可能な高分子領域に まで分子量を高めることができなかったこと，さらに は融点が低くほとんどの脂肪族ポリエステルが $100^{\circ} \mathrm{C}$ 以下であること，などがあげられる，ただし，当社で は特定組成の脂肪族ポリエステルが分子量を高めるこ とによって，実用に耐える物性を示すこと，ならびに 生分解性のあることを確認し，ビオノーレを開発する ことができ, 平成 5 年夏に半量産プラントの稼動を予 定している.ビオノーレの一般式は

$$
\left(\mathrm{O}-\left(-\mathrm{CH}_{2}\right){ }_{n} \mathrm{O}-\stackrel{\mathrm{O}}{\mathrm{C}}\left(-\mathrm{CH}_{2}\right)_{m} \stackrel{\stackrel{\mathrm{C}}{\mathrm{C}}\}_{M}}{ }\right.
$$

で示され, $n=2 \sim 4, \quad m=2 \sim 10$ の範囲で, 融点 $90 \sim$ $120^{\circ} \mathrm{C}$ のものである.

数平均分子量は $3 \sim 5$ 万位，分子量ならびに分子量
分布のコントロールは可能で, 成形品, 成形方法に応 じての対応ができる（図 1)。

当社では，ビオノーレを生分解性を伴った汎用ポリ マーと位置づけており，少くともポリオレフィンクラ スの物性に加え, 既存の成形機で容易に成形できるこ とを目標としているが, 現在までのテスト結果ではイ ンフレーション法によるフィルムを始めブロー成形 品，射出成形品のいずれもが既存の成形機をそのまま 用いて成形可能なことが確認されている. 物性的には ポリオレフィンよりもむしろ融点の低いポリエチレン テレフタレート (PET) とみた方が良く, 強度, ガス バリヤー性などは PET 類似となっているが, 反面七 ートシール性のあることなどはポリエチレンに似てい る、フィルム物性の一部を図 2 に示すが，ポリエチレ ンの 2〜5 倍位の強度があり，PET なみである。した がって，ポリオレフィンと PET の中間に位置するプ ラスチックとみることもでき，これに生分解性の加わ ったものがビオノーレと把えられる、コスト面での最 終目標はPET なみとすることである。

生分解性は品種により大幅に異なっており，物性を ほぼ同一レベルに置いて分解性をある程度コントロー ルすることは可能であるが，最も分解しやすい夕イプ で土中 2 力月位から，また最も困難なもので 6 力月位 で分解の微候を見せ始める。ほぼ倍位 の期間内で消失する。高度に延伸した フィルムは，未延伸フィルムまたは成 形品の 2 3 倍位の期間を要する。た だし，温度，土の種類により相違する ことはもちろんで, 細菌の特定化が行 われている。また，現在生分解テスト として規格化される動きのある活性污 泥中での, 特定期間内のガス発生によ るものでは, 分解が認められない, 耐 水性, 而溶剂性の優れていることが原 因とみられている（活性污泥中では時 間を要するが分解する).

（注）一軸延伸フィルム, MFR $4.4 \mathrm{~g} / 10$ 分, 引張速度 100 $\mathrm{mm} /$ 分

図 2 ビオノーレ\#2000のフィル ム厚みと引張強度の関係例
(昭和高分子 (株) - 常務理事, 開発企 画部長，専門＝熱硬化性樹脂） 